\title{
DOCHODZENIE ODSZKODOWAŃ Z CZYNÓW NIEDOZWOLONYCH NA ZASADZIE SŁUSZNOŚCI
}

Odpowiedzialność cywilna z tytułu czynów niedozwolonych w prawie polskim przechodziła ewolucję i ma swoją tradycję. W kodeksie zobowiązań odpowiedzialność ta była uregulowana w art. 134-167, w kodeksie cywilnym od 1 stycznia 1965 r. do 30 sierpnia 2004 r. w art. 415-449 k.c., a od 1 września 2004 r. w art. 415-417, art. 417'-417², art. 421-449 k.c.

Odpowiedzialność odszkodowawcza nie jest instytucją jednolitą. Kodeks cywilny, za wzorem kodeksu zobowiązań, normuje odrębnie odpowiedzialność deliktową od odpowiedzialności kontraktowej. Odmiennie też zostały uregulowane zasady i przesłanki obu reżimów odpowiedzialności.

W reżimie odpowiedzialności deliktowej wyróżnia się trzy zasady: winy, ryzyka i słuszności. Każda z nich w inny sposób uzasadnia odpowiedzialność.

Przesłankami odpowiedzialności deliktowej są: powstanie szkody, zdarzenie (czyn niedozwolony), z którym ustawa łączy obowiązek odszkodowawczy i związek przyczynowy między czynem niedozwolonym a szkodą.

Względy słuszności, jako usprawiedliwienie zasady odpowiedzialności, znane były kodeksowi zobowiązań w przepisach o czynach niedozwolonych, w szczególności w art. 143 i 149. Pierwszy z nich dawał sądowi możność nałożenia na samego sprawcę obowiązku całkowitego lub częściowego odszkodowania, gdy poszkodowany nie mógł uzyskać naprawienia szkody od osób obowiązanych do nadzoru lub jeżeli osób takich w ogóle nie było.

Jeśli chodzi o odpowiedzialność Państwa i państwowych osób prawnych, to zważywszy, że niemożliwe jest całkowite pominięcie historycznej strony tego zagadnienia, poświęcam jej uwagę w granicach niezbędnego minimum.

Należy wspomnieć, że zarówno judykatura przedwojenna, jak i powojenne orzecznictwo Sądu Najwyższego stały na stanowisku, iż Państwo nie ponosi odpowiedzialności materialnej za szkody wyrządzone przez organy państwowe, gdy spełniają one funkcje aparatu przymusu, czyli za tzw. akty władcze, wynikające z imperium państwowego, jeżeli odpowiedzialności takiej nie przewidują przepisy 
szczególne. Taką szczególną odpowiedzialność przewidywały: art. $528 \S 2$ k.p.c. z 1930 r. (t. jedn. Dz.U. z 1950 r. Nr 43 poz. 394), normujący zakres odpowiedzialności Państwa za szkody wyrządzone przez komornika i art. 510 i n. k.p.k. dotyczące odszkodowania za niesłuszne oskarżenie lub skazanie.

W praktyce odpowiedzialność cywilna Państwa za szkody wyrządzone przez czyny niedozwolone jego funkcjonariuszy sprowadzała się tylko do sfery tzw. gospodarczej działalności Państwa i to z pewnymi ograniczeniami (por. orzeczenie SN z dnia 31 października 1950 r., C 226/50, PiP 1951, s. 11, s. 800). Stan prawny w tym zakresie uległ zasadniczej zmianie z dniem 28 listopada 1956 r., tj. z chwilą wejścia w życie ustawy z 15 listopada 1956 r. o odpowiedzialności Państwa za szkody wyrządzone przez funkcjonariuszów państwowych (Dz.U. Nr 54, poz. 243), która wprowadziła pełną odpowiedzialność Państwa (art. 1), a także przedsiębiorstwa państwowego za szkody wyrządzone przez ich funkcjonariuszy. Podstawowymi przesłankami odpowiedzialności Państwa w myśl art. 1 ustawy były: 1) istnienie szkody, 2) wyrządzenie szkody przez funkcjonariusza państwowego, 3) wyrządzenie tej szkody przy wykonywaniu powierzonej mu czynności. Dopiero pozytywne stwierdzenie, że szkoda została wyrządzona w warunkach określonych art. 1 ustawy, uzasadniała odpowiedzialność Państwa, jeśli zachodzą przy tym podstawy takiej odpowiedzialności przewidziane w prawie cywilnym (art. 3), albo gdy zachodziła podstawa przewidziana w art. 5, który stanowi: ,poszkodowanemu może być przyznane całkowite bądź częściowe wynagrodzenie nawet $\mathrm{w}$ razie braku podstaw odpowiedzialności Państwa wg przepisów prawa cywilnego, jeżeli wskutek czynności pracownika państwowego doznał uszkodzenia ciała lub rozstroju zdrowia albo utracił żywiciela, a za naprawieniem szkody przemawiają względy słuszności zwłaszcza niezdolność poszkodowanego do pracy lub jego ciężkie położenie materialne.” Należy jednak zaznaczyć, że według art.1 tej ustawy „Państwo odpowiada za szkodę wyrządzoną przez funkcjonariusza państwowego przy wykonywaniu powierzonej mu czynności”, co jest powtórzeniem warunku z art. 145 k.z.

Sąd Najwyższy, w uzasadnieniu uchwały Siedmiu Sędziów z dnia 9 listopada 1959 r., 1 CO 33/59, wpisanej do księgi zasad prawnych (OSN 1960, poz. 5) podniósł, że wymieniona ustawa w zakresie objętym art. 1 uzupełnia przepisy prawa cywilnego, obok bowiem podstaw odpowiedzialności według przepisów tego prawa kreuje w art. 5 dalszą samodzielną podstawę odpowiedzialności Państwa za szkody wyrządzone przez funkcjonariuszy państwowych, a mianowicie zasadę słuszności i że w tym właśnie wyczerpuje się treść art. 5.

Podobnie w wyroku z 19 czerwca 1974 r., II CR 268/74, LEX nr 7528 Sąd Najwyższy wyjaśnił, że: „Powierzenie wykonania czynności w rozumieniu tego przepisu (obecnie art. 417 k.c.) nie musi być wyraźne i nie musi odnosić się do konkretnej czynności. Może ono wynikać także z rodzaju zajmowanego przez funkcjonariusza stanowiska i charakteru czynności." 
Artykuł 6 powołanej ustawy z 15 listopada 1956 r., który nie został uchylony po wejściu w życie Kodeksu cywilnego, rozszerza działanie ustawy również na szkody powstałe przed jej wejściem w życie, za które Państwo według dotychczasowych przepisów nie ponosiło odpowiedzialności, jednak pod poniższymi warunkami:

a) roszczeń o wynagrodzenie szkody można dochodzić od Państwa nie później niż w ciągu roku od dnia wejścia w życie ustawy. Jest to więc termin zawity (prekluzyjny) prawa materialnego, do którego miały zastosowanie art. 114117 przep. og. pr. cyw.

b) nie można dochodzić takich roszczeń, które w dniu wejścia ustawy w życie byłyby już przedawnione przy uwzględnieniu trzyletniego okresu przedawnienia, a dla roszczeń o wynagrodzenie za uszkodzenie ciała, rozstrój zdrowia lub utratę żywiciela - przy uwzględnieniu dziesięcioletniego okresu przedawnienia, jeżeli szkoda wynikła ze zbrodni lub występku.

Wprawdzie przepis art. 6 ust. 2 nie określa od jakiej daty liczy się bieg terminu przedawnienia, jednak kwestię tę normował wówczas art. 283 k.z. stanowiąc, że trzyletni termin przedawnienia liczy się od dnia, w którym poszkodowany dowiedział się o szkodzie i o osobie obowiązanej do jej naprawienia, a dziesięcioletni termin od dnia popełnienia przestępstwa. ${ }^{1}$

Tak określony termin prekluzyjny w art. 6 mógł ulec przekształceniu w termin przedawnienia dopiero od dnia 1 stycznia 1965 r. (por. art. XIII przepisów wprowadzających Kodeks cywilny), jednakże pod warunkiem, że w tym dniu jeszcze biegł (tak SN w wyroku z 2 lutego 2001 r., I CKN 1049/00, LEX nr 52461).

Przepisy art. 1-8 powołanej ustawy zostały następnie włączone do kodeksu cywilnego (art. 417-421 k.c.), a podstawowe reguły stosowania tych przepisów kodeksu wyznaczyła uchwała pełnego składu Izby Cywilnej SN z 15 lutego 1971 r., III CZP 33/70 (OSNCP 1971, nr 4, poz. 59). W przepisach art. 417-421 kodeks cywilny przejął podstawowe unormowania ustawy z dnia 15 listopada 1956 r. o odpowiedzialności Państwa za szkody wyrządzone przez funkcjonariuszów państwowych (Dz.U. Nr 54, poz. 243). Kodeks, podobnie jak czyniła to powyższa ustawa, przewiduje odpowiedzialność Państwa za szkody wyrządzone przy wykonywaniu zarówno czynności o charakterze władczym (aktów władzy), jak i czynności gospodarczych oraz normuje w sposób jednolity zasady odpowiedzialności Skarbu Państwa i organizacji państwowych, mających odrębną osobowość prawną, za ich funkcjonariuszy.

Przyjęcie w kodeksie - za wzorem ustawy z dnia 15 listopada 1956 r. - stosunkowo szerokiej odpowiedzialności majątkowej Skarbu Państwa i państwowych osób prawnych za szkodliwe skutki działalności pracowników państwowych oraz osób działających na zlecenie organów Państwa jest wyrazem dążenia ustawodawcy do

1 J. Pietrzykowski, Nowe przepisy o odpowiedzialności Państwa i państwowych osób prawnych za szkody wyrządzone przez ich funkcjonariuszy, „Przegląd zagadnień socjalnych” 1957, z.1, s. 30. 
zapewnienia pełnej praworządności, jak również do rozszerzenia zakresu ochrony usprawiedliwionych interesów obywateli. Jest więc wyrazem zasady, że wszystkie organy władzy, administracji i gospodarki państwowej obowiązane są w swojej działalności ściśle przestrzegać przepisów i zasad współżycia społecznego oraz że w razie ujemnych skutków tej działalności, powstałych z winy funkcjonariusza państwowego, a w wyjątkowych sytuacjach również mimo braku tej winy, Skarb Państwa lub państwowa osoba prawna obowiązane są do naprawienia wyrządzonej obywatelowi szkody.

Szczególną odpowiedzialność na zasadzie słuszności, określaną przez niektórych przedstawicieli doktryny odpowiedzialnością na zasadach współżycia społecznego ${ }^{2}$ przejął z tej ustawy z dniem 1 stycznia 1965 r. - art. 419 k.c., według którego: „W wypadku gdy Skarb Państwa nie ponosi według przepisów niniejszego tytułu odpowiedzialności za szkodę wyrządzoną przez funkcjonariusza państwowego przy wykonywaniu powierzonej mu czynności, poszkodowany może żądać całkowitego lub częściowego naprawienia szkody przez Skarb Państwa, jeżeli doznał uszkodzenia ciała lub rozstroju zdrowia albo utracił żywiciela, a z okoliczności, zwłaszcza ze względu na niezdolność poszkodowanego do pracy albo ze względu na jego ciężkie położenie materialne, wynika, że wymagają tego zasady współżycia społecznego". Od 1 września 2004 r. odpowiedzialność tę reguluje art. $417^{2}$ k.c., który przewiduje obowiązek naprawienia szkody wyrządzonej zgodnym z prawem wykonywaniem władzy publicznej, z tym że wyłącznie szkody na osobie, a nie szkody w mieniu. Uregulowanie to uwzględnia przyjętą przez Komitet Rady Europy 18 września 1984 r. w rekomendacji nr R/84/15 w sprawie odpowiedzialności władzy publicznej zasadę możliwości przyznania odszkodowania także wówczas, gdy władza publiczna działa legalnie, jednak niesłuszne, niehumanitarne byłoby obciążenie skutkami szkody samego poszkodowanego.

Przesłankami koniecznymi do zastosowania art. 419 k.c. były:

1) wyrządzenie szkody przez funkcjonariusza państwowego przy wykonywaniu powierzonej mu czynności;

2) powstanie szkody na osobie (doznanej wskutek uszkodzenia ciała lub rozstroju zdrowia albo utraty żywiciela rodziny),

3) zasadność przyznania odszkodowania w świetle zasad współżycia społecznego.

Wyjątkowa odpowiedzialność na zasadzie słuszności aktualizuje się wówczas, kiedy brak jest podstaw do dochodzenia roszczenia odszkodowawczego na zasadach ogólnych, ale istnieją ważne racje przemawiające za kompensacją szkody. Ochrona poszkodowanego na podstawie art. $417^{2}$ k.c. sięga dalej niż przewiduje to art. 77 
ust. 1 Konstytucji, który określa jedynie minimum ochrony jednostki i tym samym dopuszcza ochronę dalej idącą w ustawodawstwie zwykłym. ${ }^{3}$

Przesłankami odpowiedzialności na podstawie art. $417^{2}$ k.c. są:

- wykonywanie zgodnie z prawem władzy publicznej;

- powstanie szkody na osobie;

- adekwatny związek przyczynowy między aktem władzy publicznej a szkodą;

- zasadność przyznania odszkodowania w świetle zasad słuszności.

Należy podkreślić, że między unormowaniem art. 419 k.c. a art. $417^{2}$ k.c. występuje istotna różnica. Odpowiedzialność Skarbu Państwa na podstawie art. 419 k.c. zachodziła wówczas, kiedy działanie funkcjonariusza państwowego, które wyrządziło szkodę, zostało podjęte w interesie powszechnym, a nie indywidualnym. Reguły stosowania art. 419 k.c. zmienił wyrok Trybunału Konstytucyjnego z 4 grudnia 2001 r., SK 18/2000, przez rezygnację z wymagania, aby wyrządzający szkodę funkcjonariusz działał niezgodnie $\mathrm{z}$ prawem $\mathrm{i}$ aby to działanie było podjęte tylko w interesie publicznym. Po tym wyroku, już na gruncie art. 419 k.c., przyjmowano, że odszkodowanie może być przyznane także wówczas, gdy w konkretnych okolicznościach powodem działania sprawczego był interes indywidualny. Ten kierunek wykładni został przyjęty w art. $417^{2}$ k.c. oczywiście, jeżeli za przyznaniem odszkodowania przemawiają względy słuszności (zasady współżycia społecznego), a więc gdy np. doznanie przez poszkodowanego na skutek działania funkcjonariusza państwowego trwałego, dotkliwego rozstroju zdrowia, spowodowało niezdolność do pracy oraz szczególnie ciężkie położenie materialne itp. Takiemu stanowisku dał wyraz SN w wyroku z 25 listopada 2003 r., II CK 286/02, Biul. SN 2004, nr 4, s. 10 stwierdzając: „Okoliczność, że działanie funkcjonariusza państwowego, które wyrządziło szkodę, nie zostało podjęte w interesie powszechnym, a w tym celu, żeby chronić dobro poszkodowanego, nie wyłącza odpowiedzialności Skarbu Państwa na podstawie art. 419 k.c. Dla odpowiedzialności tej konieczne jest jednakże istnienie innych szczególnych okoliczności, które by sprawiały, że za przyznaniem odszkodowania przemawiają względy słuszności (zasady współżycia społecznego). Okolicznościami tymi może być doznanie przez poszkodowanego na skutek działania funkcjonariusza państwowego trwałego, dotkliwego rozstroju zdrowia, powodującego w szczególności niezdolność do pracy oraz szczególnie ciężkie położenie materialne, w jakim poszkodowany znalazł się ze względu na stan swego zdrowia spowodowany wspomnianym działaniem funkcjonariusza państwowego".

Jako okoliczności prawnie relewantne, obok wskazanych w przepisie art. 419 k.c. (niezdolność poszkodowanego do pracy, trudne położenie materialne) powinno się wziąć pod uwagę znaczenie naruszonego dobra, zakres doznanych uszczerbków, zachowanie poszkodowanego (por. wyrok SN z 6 stycznia 1975 r., II CR 779/74, 
LEX nr 7637. Sąd Najwyższy w wyroku z 22 maja 2003 r., II CKN 96/01, LEX nr 137609) stwierdził, że dla oceny, czy zasady współżycia społecznego uzasadniają w konkretnej sprawie przyznanie odszkodowania, nie bez znaczenia jest również zachowanie się samego poszkodowanego. Nie ma podstaw do zasądzenia odszkodowania, na podstawie art. 419 k.c., w sytuacji gdy poszkodowany doznał szkody wskutek zgodnej z prawem i niezawinionej interwencji funkcjonariuszy państwowych, jeżeli sam swoim zachowaniem, naruszającym zasady współżycia społecznego, tę interwencję spowodował.

Trybunał Konstytucyjny w powołanym wyroku z 4 grudnia 2001 r. wyjaśnił pojęcie władzy publicznej w rozumieniu art. 77 ust. 1 Konstytucji, stwierdzając m.in., że obejmuje ono wszystkie władze w sensie konstytucyjnym, a więc ustawodawczą, wykonawczą i sądowniczą, przy czym pojęcia organu państwa oraz organu władzy publicznej nie są tożsame. W pojęciu władzy publicznej mieszczą się bowiem także inne instytucje niż państwowe lub samorządowe, jeżeli wykonują funkcje władzy publicznej w wyniku powierzenia czy przekazania im tych funkcji przez organ władzy państwowej. Pojęcie to musi być tak samo rozumiane na tle art. $417^{2}$ k.c., jak i art. 417 k.c.

Przepis art. $417^{2}$ k.c. nie wskazuje, jak należy oceniać przesłankę związku przyczynowego. Dyskusyjne jest też, czy znajduje tu zastosowanie ogólna zasada wyrażona w art. $361 \S 1$ k.c. Niektórzy przedstawiciele doktryny ${ }^{4}$ opowiadają się za złagodzeniem kryterium normalności tego związku w świetle odpowiedzialności na zasadzie słuszności, wskazując jako argument szkody spowodowane szczepieniami ochronnymi (por. też wyrok SN z dnia 20 sierpnia 1968 r., II CR 310/68, z glosą M. Sośniaka, OSP 1969, nr 3, poz. 67).

Zakres pojęcia „szkody na osobie” wyjaśnił Sąd Apelacyjny w Warszawie w wyroku z 5 lutego 2014 r. I ACa 1618/13, LEX nr 1455663 stwierdzając, że:

„W art. $417^{2} \mathrm{kc}$. chodzi o takiego rodzaju uszczerbki, które dotyczą osoby fizycznej, są więc związane z dobrami osobistymi takiej osoby, jak życie, zdrowie, w tym sprawność intelektualna i manualna, wolność twórczości oraz wszelkiej innej aktywności życiowej, która może mieć istotny wpływ na dalsze życie konkretnej osoby fizycznej, w tym możliwość działania, zarobkowania i zaspokajania swoich wszelkich potrzeb, nie może być jednak utożsamiana z jej zasobnością majątkową. Konieczność odróżnienia podmiotu posiadającego określony majątek od samej osoby właściciela przekłada się w oczywisty sposób na potrzebę rozróżnienia szkody majątkowej od szkody na osobie oraz możliwość określenia odrębnych zasad naprawiania tych szkód."

4 Z. Radwański, Zobowiązania - część ogólna, Warszawa 2003, s. 192; M. Safjan, Odpowiedzialność odszkodowawcza władzy publicznej 2009, s. 137; A. Śmieja, Związek przyczynowy i zasady współżycia społecznego w świetle art. 419 k.c., „Acta Universitatis Wratislaviensis” 1990, z. 186, s. 331; G. Bieniek, (w:) Komentarz do Kc, Ks. III, t.I, Warszawa 2011, s. 462. 
Jeśli szkoda na osobie powstaje wskutek naruszenia dóbr osobistych poszkodowanego, a w szczególności uszkodzenia ciała lub wywołania rozstroju zdrowia (art. 444 § 1 k.c.), naprawienie dotyczyć będzie majątkowych i niemajątkowych uszczerbków w dobrach osobistych poszkodowanego, natomiast ochroną nie jest objęte mienie poszkodowanego. Poszkodowany może żądać nie tylko naprawienia szkody majątkowej, ale także zadośćuczynienia pieniężnego za doznaną krzywdę, gdy okoliczności, a zwłaszcza niezdolność poszkodowanego do pracy lub jego ciężkie położenie materialne, wskazują, że wymagają tego względy słuszności.

Osobą uprawnioną do dochodzenia roszczenia jest bezpośrednio poszkodowany, ponieważ art. $417^{2}$ k.c. - inaczej niż uchylony art. 419 k.c. - nie uprawnia do odszkodowania innej osoby, która wskutek śmierci bezpośrednio poszkodowanego utraciła żywiciela. W doktrynie pojawiają się też słuszne głosy, aby zakresem zastosowania art. $417^{2}$ k.c. objąć także osobę pośrednio poszkodowaną, tak jak to czyni art. 446 k.c.

Ustawa nie definiuje pojęcia ,względy słuszności”, jednak dokonana zmiana „zasad współżycia społecznego” na ,względy słuszności” uzasadnia rozumienie obu pojęć tak samo. Zatem zachowały aktualność poglądy doktryny i judykatury co do rozumienia zasad współżycia społecznego. ${ }^{5}$

Na uwagę zasługuje wyrok SN z 7 marca 2013 r., II CSK 364/12 z aprobującą glosą K. Bączyk-Rozwadowskiej (OSP 2014/2/16) dotyczący odpowiedzialności Skarbu Państwa za szkody powstałe w wyniku zaniechania przy wykonywaniu władzy publicznej, w którym stwierdził, że „Skarb Państwa może ponieść odpowiedzialność na zasadach słuszności za szkodę doznaną w następstwie zakażenia bakteryjnego przez żołnierza, który - odbywając służbę zasadniczą - znajduje się w sferze władzy publicznej jednostki wojskowej (art. $417^{2}$ k.c.). Uwzględnienie stopy życiowej społeczeństwa przy określaniu wysokości zadośćuczynienia nie może podważać jego kompensacyjnej funkcji”.

W sprawie tej powód w czasie odbywania służby wojskowej został poddany szczepieniom ochronnym przeciwko durowi brzusznemu i tężcowi, w wyniku którego stał się inwalidą trwale niezdolnym do pracy i samodzielnej egzystencji (zmiany martwiczo-krwotoczne obejmujące 50\% ciała i amputacja obu kończyn dolnych, a stopień uszczerbku na zdrowiu biegli ocenili na 120\%). Z uwagi na kwestionowanie przez pozwany Skarb Państwa jakoby do szkody powoda doszło przy wykonywaniu przez pozwanego władzy publicznej, Sąd Najwyższy podkreślił, że pojęcie to nie może być ograniczone jedynie do ściśle pojętego imperium, ale obejmuje swym zakresem wszystkie formy wykonywania zadań publicznych, nawet pozbawionych elementu władczego, ale wpływających na sytuację prawną jednostki. Sytuacja taka zaistniała w rozpoznawanej sprawie, skoro powód był w sytuacji faktycznego i prawnego przymusu, stawiając się do pozwanej jednostki celem odbycia 
obowiązkowej służby wojskowej, a jak się okazało, po obowiązkowych szczepieniach obniżających jego odporność, został narażony na zakażenie chorobą zakaźną, której źródło znajdowało się na terenie jednostki wojskowej. Niezależnie od tego Sąd Najwyższy podzielił linię orzecznictwa w sprawach dotyczących zadośćuczynienia stwierdzając, że potrzeba utrzymania jego wysokości w rozsądnych granicach, odpowiadających aktualnym warunkom i przeciętnej stopie życiowej społeczeństwa ma jedynie charakter uzupełniający w stosunku do rozmiaru szkody niemajątkowej i nie może prowadzić do podważenia kompensacyjnej funkcji zadośćuczynienia (por. między innymi wyroki Sądu Najwyższego z 12 września 2002 r., IV CKN 1266/00, Lex nr 80272; z 30 stycznia 2004 r., I CK 131/03, OSNC 2005/2/40; z 10 marca 2006 r., IV CSK 80/05, OSNC 2006/10/175, z 26 listopada 2009 r., III CSK 62/09, Lex nr 738354; z 17 września 2010 r., II CSK 94/10, OSNC 2011/4/44).

Roszczenie oparte na zasadzie słuszności ulega przedawnieniu przewidzianemu dla roszczeń z czynów niedozwolonych, a więc na zasadach określonych w art. 442 k.c. (obecnie $442^{1}$ k.c.). Takiemu stanowisku dał wyraz Sąd Najwyższy w wyroku z 30 maja 1969 r., II CR 171/69, Biul. Inf. SN 1969, nr 12, poz. 215) w czasie obowiązywania art. 419 k.c., który zachowuje aktualność w świetle art. $417^{2}$ k.c.

Odpowiedzialność na zasadzie słuszności regulują też:

- art. 428 k.c. przewidujący możliwość domagania się na zasadzie słuszności naprawienia szkody od samego sprawcy, któremu ze względu na wiek, stan psychiczny lub fizyczny winy poczytać nie można - gdy brak jest osoby zobowiązanej do nadzoru albo nie można domagać się odszkodowania od takiej osoby. Przepis ten wprowadza więc osobistą odpowiedzialność osoby, która według ogólnych zasad odpowiedzialności (art. 415 k.c.) nie może odpowiadać ze względu na niemożność przypisania jej winy własnej. Przypisanie odpowiedzialności małoletniemu lub niepoczytalnemu sprawcy szkody wymaga ustalenia, że względy prawne lub faktyczne uniemożliwiają naprawienie szkody przez osoby zobowiązane do nadzoru.

Zobowiązanie do naprawienia szkody na podstawie tego przepisu powstanie tylko wtedy, gdy działanie bezpośredniego sprawcy miało charakter bezprawny, bowiem tylko wiek, stan psychiczny lub cielesny nie pozwala postawić zarzutu winy. Kryterium do zastosowania tego przepisu jest porównanie stanu majątkowego poszkodowanego i sprawcy.

- art. 431 k.c. - regulujący odpowiedzialność za szkody wyrządzone przez zwierzęta na zasadzie winy $\mathrm{w}$ nadzorze. Przepis ten dotyczy tylko takich sytuacji, w których zwierzę wyrządza szkodę z własnego popędu, a więc w wyniku samoistnego, niezależnego od człowieka zachowania się. Jeżeli natomiast jest tylko narzędziem w ręku człowieka, odpowiedzialność za szkodę opiera się na art. 415 k.c.

$\mathrm{W}$ razie przeprowadzenia dowodu braku winy w nadzorze zostanie wyłączona odpowiedzialność na podstawie art. $431 \S 1$, ale może powstać obowiązek naprawie- 
nia szkody na zasadzie słuszności na podstawie art. $431 \S 2$ k.c. Przepis ten reguluje szczególny przypadek odpowiedzialności, jeżeli z okoliczności wynika, że wymagają tego zasady współżycia społecznego. Wprawdzie ustawodawca w przepisie tym nawet przykładowo nie wskazuje żadnej okoliczności na rzecz zasady słuszności, jednak ogólne odwołanie się do zasad współżycia społecznego uzasadnia, tak jak w art. 428 k.c., porównanie stanu majątkowego poszkodowanego i odpowiedzialnego za zwierzę.

\section{Wybrane tezy z orzecznictwa}

Treść art. 5 ustawy z dnia 15 listopada 1956 r. o odpowiedzialności Państwa za szkody wyrządzone przez funkcjonariuszów państwowych wyczerpuje się $\mathrm{w}$ tym, że w ramach hipotezy normy art. 1 uzupełnia on - zasadą słuszności - podstawy odpowiedzialności Państwa przewidziane w powszechnym prawie cywilnym. W ten sposób art. 5 stanowi rozszerzenie przepisu art. 3, z czego jednak nie wynika, aby art. 5 miał sięgać poza hipotezę art. 1 ustawy (wyrok SN z 22 kwietnia 1961 r. II CR 912/60 OSNC 1962/2/68).

Szczególnym przepisem jest art. 5 cyt. ustawy, który przewiduje jako podstawę odpowiedzialności Państwa względy słuszności, dopuszcza możliwość przyznania poszkodowanemu całkowitego lub częściowego wynagrodzenia szkody nawet w razie braku podstaw odpowiedzialności Państwa według przepisów prawa cywilnego, a tym samym nie wyłącza jej również w wypadku, gdy szkoda powstała nie przy wykonywaniu, lecz przy okazji wykonywania powierzonej czynność (wyrok SN z 28 września 1957 r., II CR 1086/56, OSNPG 1958/12/68).

Uzależnienie powstania odpowiedzialności odszkodowawczej od tego, czy działanie funkcjonariusza miało na celu ochronę interesu ogólnego, czy też dobra poszkodowanego, stanowi nieuzasadnione ograniczenie stosowania art. 419 k.c., statuującego odpowiedzialność Skarbu Państwa na zasadzie słuszności w celu ochrony uzasadnionych interesów poszkodowanych.

Dla spełnienia humanitarnego celu realizowanego przez art. 419 k.c. można odstąpić od wymagania, aby między szkodą a zachowaniem się funkcjonariusza istniał normalny związek przyczynowy, a poprzestać na ustaleniu istnienia niekwalifikowanego powiązania kauzalnego (wyrok SN z 4 marca 2008 r., IV CSK 453/07, LEX nr 371407).

Norma art. $417^{2}$ k.c. zawiera regulację prawną odpowiedzialności za szkodę wyrządzoną takim wykonywaniem władzy publicznej, któremu nie można przypisać cechy bezprawności (tzw. szkody legalne). Celem tej regulacji prawnej, która wykracza poza minimalny standard ochrony jednostki określony przez art. 77 ust. 1 Konstytucji RP, jest zapewnienie poszkodowanym kompensaty szczególnie dotkliwych uszczerbków spowodowanych władczą działalnością jednostek państwa i samo- 
rządu terytorialnego, jeżeli przemawiają za tym normy etyczne, a wobec zgodnego z prawem zachowania sprawcy usunięcie tych następstw nie jest możliwe na podstawie przepisów ogólnych. Szkoda na osobie powstaje wskutek naruszenia dóbr osobistych poszkodowanego, a w szczególności uszkodzenia ciała lub wywołania rozstroju zdrowia. Przy czym dla zasądzenia odszkodowania na tej podstawie musi zostać zachowana tego rodzaju łączność przyczynowo-skutkowa pomiędzy zdarzeniem powodującym szkodę a szkodą, że bez określonego działania funkcjonariusza (choćby w pełni prawidłowego) nie doszłoby do powstania szkody w postaci uszkodzenia ciała czy rozstroju zdrowia. Odmienność sytuacji, w której przyczynę szkody ma stanowić zaniechanie, a zatem kiedy ocena związku przyczynowego przebiega w oparciu o hipotetyczne założenie, iż określone działanie, gdyby zostało podjęte, zapobiegłoby szkodzie, wymaga wskazania tego niezbędnego działania zapobiegawczego i stwierdzenia, że istniała obiektywna potrzeba i możliwość jego podjęcia.

$\mathrm{W}$ art. $417^{2}$ k.c. wprowadzona została podstawa prawna dla przyznania osobie fizycznej odszkodowania oraz zadośćuczynienia, ale tylko tytułem naprawienia szkody na osobie, która została wywołana zgodnym z prawem wykonywaniem władzy publicznej przez różnego rodzaju organy państwa, taka możliwość nie została natomiast przewidziana jako sposób naprawienia szkody majątkowej, obejmującej straty, jak również utracone korzyści, stosownie do art. $361 \S 2$ k.c. (wyrok SA w Katowicach z 6 lutego 2014 r., I ACa 1059/13, LEX nr 1437959).

Skarb Państwa może ponieść odpowiedzialność na zasadach słuszności za szkodę doznaną w następstwie zakażenia bakteryjnego przez żołnierza, który - odbywając służbę zasadniczą - znajduje się w sferze władzy publicznej jednostki wojskowej (art. $417^{2}$ k.c.). Uwzględnienie stopy życiowej społeczeństwa przy określaniu wysokości zadośćuczynienia nie może podważać jego kompensacyjnej funkcji (wyrok SN z 7 marca 2013 r., II CSK 364/12, OSP 2014/2/16).

\section{Podsumowanie}

Zagadnienie dochodzenia odszkodowań z czynów niedozwolonych na zasadzie słuszności, szczególnie odpowiedzialności Państwa oraz państwowych osób prawnych za szkody wyrządzone przez ich funkcjonariuszy, ma duże znaczenie społeczne.

Słusznie więc ustawą z dnia 15 listopada 1956 r. o odpowiedzialności Państwa za szkody wyrządzone przez funkcjonariuszów państwowych (Dz.U. Nr 54, poz. 243) wprowadzono zasady pełnej odpowiedzialności Państwa oraz państwowych osób prawnych za szkody wyrządzone przez ich funkcjonariuszy podczas wykonywania powierzonych im czynności, niezależnie od tego, czy czynności te dotyczą sfery działalności gospodarczej Państwa, czy też mają charakter aktów władczych organów Państwa jako aparatu przymusu. 
Brak $\mathrm{w}$ dotychczasowym stanie prawnym zasady pełnej odpowiedzialności sprawiał, że Państwo przed wejściem w życie ustawy odpowiadało za szkody wyrządzone przez funkcjonariuszy państwowych przy wykonywaniu aktów władczych tylko o tyle, o ile odpowiedzialność taką uzasadniał szczególny przepis prawa.

Zasada pełnej odpowiedzialności Państwa nie oznacza jednak, że Państwo ponosi nieograniczoną odpowiedzialność za szkody wyrządzone przez swych funkcjonariuszy. Ustawa zakreśla bowiem jednocześnie w art. 1 generalne granice (ramy) tej odpowiedzialności. Przepis ten wprowadził naczelną zasadę, że Państwo odpowiada za szkodę wyrządzoną przez funkcjonariusza państwowego ,przy wykonywaniu powierzonej mu czynności”. Trafnie więc tę szczególną odpowiedzialność na zasadzie słuszności, określaną przez niektórych przedstawicieli doktryny odpowiedzialnością na zasadach współżycia społecznego, przejął ustawodawca z tej ustawy z dniem 1 stycznia 1965 r. do art. 419 k.c., a następnie wprowadził z dniem 1 września 2004 r. - do art. $417^{2}$ k.c.

Z pełną aprobatą należy też się odnieść do ugruntowanego stanowiska Sądu Najwyższego co do tego, że:

- wykonywanie władzy publicznej nie może być ograniczone jedynie do ściśle pojętego imperium, ale obejmuje swym zakresem wszystkie formy wykonywania zadań publicznych, nawet pozbawionych elementu władczego, lecz wpływających na sytuację prawną jednostki,

- do udowodnienia związku przyczynowego w sferze szkód na osobie wystarczające jest wykazanie wysokiego stopnia prawdopodobieństwa między wykonywaniem władzy publicznej a szkodą,

- potrzeba utrzymania wysokości zadośćuczynienia w rozsądnych granicach, odpowiadających aktualnym warunkom i przeciętnej stopie życiowej społeczeństwa ma jedynie charakter uzupełniający w stosunku do rozmiaru szkody niemajątkowej i nie może prowadzić do podważenia kompensacyjnej funkcji zadośćuczynienia. 


\section{VINDICATION OF CLAIMS FOR TORT DAMAGES}

BASED ON THE PRINCIPLE OF EQUITY

The article includes a discussion of the rules governing liability for damages on an equitable basis. Considerations apply in particular tort liability. The author discusses the title issue from the point of view of personal experience of the Supreme Court judge. Theoretical issues are discussed on the example of judicial decisions.

Keywords: civil responsibility, delicts, principle of equity 